Ela regressou para Jaroslaw, na Polônia. A linhagem feminina - a mãe, Bertha, a avó, Rosa Stieglitz - era famosa, lá, pelo talento e pela energia com que essas mulheres assumiam as rédas da economia familiar, Bertha como modista e Rosa como parteira.

Indo todos os anos às capitais da moda de então, Viena e Paris, Bertha trazia para sua clientela, ávida de novidades, sempre a mais recente tendência fashion. Foi ela quem instou a filha Lotka a ir para Paris, conseguindo-lhe um estágio em uma famosa modista francesa da Avenue Montignon. Aí começaria tudo, na vida da jovem judia imigrante que se tornaria modelo, descobriria Claudel e Péguy, viveria um amor lésbico e, casando-se com Prévaux, desempenharia missões perigosas na Resistência
Francesa, até sua morte.

Rompendo limites de classe social, religião e cultura, aí incluídos os dos papéis tradicionais de gênero, a história da resistência de Jaques e Lotka, tal como reconstituída e narrada por sua única filha, Aude Yung-de Prévaux, que um dia abriu as malas ancestrais sobre o tapete $e$ encarou o enigma das fotos antigas, dos velhos papéis em busca de uma resposta à pergunta "quem sou?", emociona e seduz a todos nós.

1 Tradução de Un amour dans la tempête de l'histoire: Jacques et Lotka.

Maria Consuelo Cunha Campos Universidade do Estado do Rio de Janeiro

\title{
Mulheres, raça e cristianismo popular no Brasil
}

\author{
Blessed Anastácia: Women, \\ Race, and Popular Christianity in \\ Brazil.
}

BURDICK, John.

New York/London: Routledge, 1998. $246 \mathrm{p}$.

Começo esta resenha pelo fim: ao terminar a leitura desse livro, perguntei-me se o movimento negro no Brasil já o descobriu. Creio ser urgente sua tradução, tanto pelo peso acadêmico de sua contribuição - conteúdo (discussão teórica e política dos movimentos sociais) e metodologia como por sua contribuição a discussões específicas dos movimentos negros em nosso país. O autor não teme a explicitação de sua posição de "pesquisador engajado": Ele quer, com esse estudo, contribuir para 0 desenvolvimento da identidade de seu interlocutor principal, o movimento negro brasileiro, bem como de suas táticas e objetivos. John Burdick, professor de Antropologia na Syracuse University, USA, já é conhecido entre nós por uma obra anterior. ${ }^{1}$ Agora, o autor volta ao tema da religião popular e nos oferece um excelente trabalho antropológico em que questões de raça, gênero, religião e cultura popular mesclam-se, tendo como inspiração, por assim dizer, a figura da escrava negra torturada e tornada 'santa' por suas/seus fiéis devotos. No correr do livro, Burdick vai mostrando o que significa, para ele, fazer um estudo antropológico, explicitando na conclusão várias questões fundamentais à metodologia dessa tarefa.

Logo na introdução, fica claro que, para o autor o livro não é sobre Anastácia em si, mas sobre o racismo e sua expressão através da religião. Sensibilizado pela crueldade e injustiça da opressão devida à cor da pele no Brasil, diz que "a questão não é mais se a cor de um/a brasileiro/a influencia suas chances de vida, mas como o faz" (p. 1). Ao trabalhar o problema central da pesquisa - o significado político da cultura popular -, leva em conta a religião como um elemento inalienável dessa cultura em nosso país e, especialmente, o Cristianismo, por sua disseminação e sua força social e política. Como lembra o autor a maioria das pessoas que se identificam como negras ou pretas são praticantes de alguma forma de Cristianismo.

O campo empírico analisado é o Pentecostalismo, a devoção à escrava Anastácia, a Missa católica afro. As entrevistadas são majoritariamente mulheres. Discutindo com ativistas do movimento negro, e diferentemente delas/es, o autor considera o Cristianismo "um idioma viável para imaginar e articular identidade étnica negra e anti-racismo" (p. 21). Atento à complexidade das questões que aborda, Burdick evita simplificações e tenta apanhar as 
contradições da realidade estudada. Mostra como nem tudo é resistência na cultura popular; nem tudo é conformismo no Pentecostalismo e, apesar da boa-vontade dos propositores, a Missa católica negra acaba por reafirmar e legitimar certos códigos culturais dominantes, ao invés de opor-se a eles. Assim, os movimentos sociais aparecem, ao mesmo tempo, como articuladores e marginalizadores de práticas sociais.

E Anastácia? Bem, sua devoção, não aceita oficialmente pela Igreja católica, e, em determinadas circunstâncias, até mesmo condenada e 'perseguida', chama a atenção para o corpo das mulheres como lugar de sofrimento, violência, tortura e morte, ainda que 'distraindo' da questão da negritude e da luta anti-racista. Diferentemente interpretada por mulatas e negras, a história de sua tortura e morte é contada pelas primeiras como um romance de amor de um homem branco por uma escrava, cujo final trágico é devido ao ciúme da esposa. Já para as negras, Anastácia é vítima de sua resistência aos avanços sexuais de seu senhor. Em ambas as versões, Anastácia torna-se um símbolo carregado de significados.

A obra compõe-se de seis capítulos e uma conclusão. O primeiro traz elementos do cotidiano de mulheres negras pobres do Rio de Janeiro: amor, família, trabalho são os principais temas abordados. A distinção feita entre negras/pretas e morenas/pardas conduz a resultados surpreendentes a partir de depoimentos pungentes.

O segundo capítulo introduz diversas versões da história de Anastácia, que, curiosamente, são distintas e têm significados diferentes, na boca de mulatas e de negras, confrontando 0 significado dela com o da figura de Zumbi.

Os três capítulos seguintes discutem, respectivamente, a Missa inculturada católica; os significados de raça e cor no Pentecostalismo e as leituras políticas da devoção católica popular à Anastácia.

O sexto capítulo ("A política da etnografia: traduzindo asserções do conhecimento para a prática") e a conclusão ("Uma agenda para a etnografia dos movimentos sociais") colocam as discussões teórico-metodológicas e políticas decorrentes do estudo realizado. Após afirmar a validade e os riscos do método pesquisa-ação, Burdick aponta para alguns resultados do estudo que podem ser úteis para os/as líderes do movimento negro no Brasil. Um deles é a erosão de estereótipos a respeito de não-participantes. O autor dialoga com uma líder do movimento negro, buscando fazê-la perceber como crenças e práticas aparentemente alienantes da consciência negra - a figura de Anastácia e a adesão ao Pentecostalismo - podem funcionar, para as aderentes, como catalisadores da consciência de raça.

Outro resultado que pode ser relevante para ativistas do movimento negro é a descoberta da defasagem existente entre o discurso da liderança e os sentimentos e atitudes de parte de suas bases. Burdick mostra como a aceitação dos objetivos do movimento não impede uma reação negativa a certas idéias veiculadas pelo mesmo. Dois exemplos da pesquisa de campo confirmam isso. Um deles vem da Missa inculturada, em que o batuque constante dos tambores é considerado parte da 'cultura' negra em oposição aos momentos de silêncio da Missa tradicional, vistos como 'coisa de branco'. Mulheres negras entrevistadas não se reconhecem nessa associação entre negritude e ritmo e dizem gostar de um ritual que inclua também o silêncio. Outro exemplo é o caso de 'mestiças/os' que se sentiriam mobilizados para a luta anti-racista se não houvesse, por parte de ativistas, uma insistência no corte brancas/os $X$ não-brancas/os, como dois blocos homogêneos.

Na conclusão, Burdick apresenta pontos metodológicos relevantes, extraídos da experiência de sua pesquisa, para o estudo de movimentos sociais. Vale citar as frases que finalizam o livro: "Através destas explorações, ouvir cuidadosamente será tão importante quanto pronunciar-se. Esta é a razão pela qual o trabalho político da etnografia está apenas começando." (p. 205).

Last but not least, vale uma palavra sobre a sensibilidade de gênero do autor. Londa Schienbinger, física feminista que teve um livro recentemente traduzido para o português, ${ }^{2}$ nos adverte que trabalhar academicamente como feminista passa antes pela consciência de gênero do que pelo fato de ser mulher. Nesse sentido, podemos, nós, feministas, acolher John Burdick em nossas fileiras. Seu livro, tendo como foco a população feminina, é revelador do quanto ganha em profundidade e agudeza uma análise que evita homogeneizações e atenta para a complexidade do real.

1 Procurando Deus no Brasil: a Igreja Católica progressista no Brasil na arena das religiões urbanas brasileiras. Rio de Janeiro: Mauad, 1998. 215 p.

${ }^{2}$ SCHIENBINGER, Londa. O feminismo mudou a ciência? São Paulo: EDUSC, 1999. 382 p.

Maria José Rosado-Nunes Pontifícia Universidade Católica de São Paulo 